logos_i_ethos_2021_1_(56), s. 75-85

DOI: http://dx.doi.org/10.15633/lie.3939

Grzegorz Hołub

https://orcid.org/0000-0002-0312-3693

Uniwersytet Papieski Jana Pawła II w Krakowie

\title{
The Validity of Karol Wojtyła's Philosophy Today
}

\section{Introduction}

It is not easy to talk about the philosophy of Karol Wojtyła. There are many reasons for that. We are going to point to some of them and consider their strength and appeal. One of the reasons is that Wojtyła was very intensely involved in the life of the Catholic Church and many perceive him as a pastor and a theologian. This is obvious against the background of his papacy when he operated as John Paul II, but also his activity as a bishop and cardinal of Cracow contribute to his perception as a religious figure. Additionally, his adult education was mostly associated with theology; for example, although he studied Polish literature and was interested in theater, he took his Ph. D. in theology at the Angelicum University in Rome and at the Jagiellonian University in Cracow.

He wrote many works having clear theological imprint and this seems to categorize him as a religious thinker. Of course, during his time in Cracow he produced a good number of articles and books on philosophy,
Rev. Grzegorz Hołub, PhD, is Professor of Philosophy at the Department of Philosophy of the Pontifical University of John Paul II in Cracow, Poland. His areas of research include bioethics, environmental ethics, and philosophy of the human person. He published books on the concept of the person in the contemporary bioethics and on various particular problems of bioethics (Problem osoby we współczesnych debatach bioetycznych, 2010; Osoba w labiryncie decyzji moralnych. Bioetyka w perspektywie personalistycznej, 2014). He also works on the problem of human enhancement and as a result he published a book concerning this topic (Ulepszanie człowieka. Fikcja czy rzeczywistość. Argumenty, krytyka, poszukiwanie plaszczyzny dialogu, 2018). Prof. Hołub is additionally interested in the thought of Karol Wojtyła. He currently resides in Cracow, Poland. 
but theology was close to him all the time. When we look at some of his philosophical works, for example Love and Responsibility, we can see that Wojtyła occasionally makes references to theological theses; also The Acting Person ${ }^{1}$ starts with a quotation taken from the Second Vatican Council's constitution Gaudium et spes. For some commentators, these circumstances can cast a shadow on Wojtyła's intentions and maybe also his qualifications as a philosopher.

Nevertheless, Karol Wojtyła was a complex figure and any attempt at a simple classification would be unjustified in his case. As we know, he was a poet, an actor, a pastor, a theologian, but he was indeed also a philosopher. He developed activities in all these fields and had remarkable achievements in many of them. Understandably, his various interests and undertakings influenced one another, but that doesn't lead us to a conclusion that they were not real in themselves. In this article we are going to concentrate on his activity as a philosopher. Of course, we are not going to repeat his biography, which is widely known and has recently been told once again in a book published as part of the Polish Christian Philosophy in the 2oth Century project. ${ }^{2}$ Our intention is to highlight some important points showing Wojtyła's rooting in the European philosophy and the validity of his achievements for the philosophical debates of today.

\section{A Walk through Philosophy}

Karol Wojtyła was interested in philosophical thought and we know that from his personal memoirs. Firstly, he was fascinated with the Thomistic philosophy and this school left a definitive imprint on his philosophical mind. However, later on in his studies he encountered other philosophers and developed some liking for them. They included St. Augustine, Immanuel Kant, and especially Max Scheler. We also know from his books and the interviews he gave as John Paul II that he appreciated

1 K. Wojtyła, Osoba i czyn, Kraków 1969, p. 5.

2 Cf. G. Hołub, T. Biesaga, J. Merecki, M. Kostur, Karol Wojtyła, Kraków 2019, p. 9-19. 
other contemporary philosophers, for example philosophers of dialogue or Emmanuel Lévinas, ${ }^{3}$ to mention but a few.

Reading the works of Wojtyła, we can see how he analyzes various philosophical concepts and finds them interesting and complementing one another. Beginning with St. Augustine and ending with contemporary philosophers. The Polish thinker discovers some interesting and worthwhile ideas which deserve our attention. He subsequently uses these as specific bricks in his own projects, especially those having to do with philosophical anthropology and ethics. In all this, he cannot be accused of eclecticism: Wojtyła does not choose to put together those ideas blindly, as if at random. He is aware that they belong to various philosophical schools, which differ between one another and cannot be easily reconciled.

As an example, we can point to his treatment of the second moral imperative as originally formulated by Immanuel Kant. In Love and Responsibilty, Wojtyła formulated this rule in the following way, "Whenever a person is the object of your activity, remember that you may not treat that person as only the means to an end, as an instrument, but must allow for the fact the he or she, too, has, or at least should have distinct personal ends." ${ }^{4}$ When we take into account the philosophy of Immanuel Kant, we realize that the German philosopher meant by a person an entity understood as a thinking subject, for he was in a sense following in the line of René Descartes's anthropological dualism. Wojtyła was far from that philosophical position. He subscribed to the thesis that the human person cannot be limited to a thinking subject, cannot be identified with consciousness. The human person - as he himself declared in the same book - also "has a body and in a certain sense is a body." In short, for Wojtyła the person is a bodily-spiritual creature and these two metaphysical dimensions are indispensable for an integral understanding

3 See K. Wojtyła, Person: Subject and Community, in: K. Wojtyła, Person and Community. Selected Essays, transl. T. Sandok, New York 1993, p. 240ff; John Paul II, Crossing the Threshold of Hope, New York 2005, p. 35-36.

${ }^{4}$ K. Wojtyła, Love and Responsibility, transl. H. T. Willetts, San Francisco 1981, p. 28.

${ }_{5}$ K. Wojtyła, Love and Responsibility, op. cit., p. 23. 
of personhood. However, Wojtyła drew heavily on this Kantian rule. He was aware that whatever metaphysical underpinning of the theory of person, a person reveals itself as a special good, having his/her own teleology. Thus, the Polish thinker and many other philosophers of various philosophical backgrounds claim that the special status of the person is marked by his or her possession of non-instrumental ends.

In this move, we can see how Wojtyła reads specific philosophical concepts in a way which can open up a dialogue between various projects and personalities. What is interesting in this is that his voice does not disappear: he is present in this internal philosophical dialogue as an autonomous interlocutor and gradually builds up his theory of the human person.

There is a dispute around the philosophy of Karol Wojtyła as to the kind of philosopher he was: an Augustinian, Thomist, Kantist, or maybe phenomenologist? Participants in this debate give various reasons supporting their position. Our interpretation of Wojtyła, taking into account all of his works, is that he began as a Thomist and in a sense remained one, but for him Thomism was not a closed system of philosophizing. At a certain point, he realized that this school of philosophy can and should be enriched. In the longer run, he developed an original version of personalism following in the line of Thomistic philosophy, but modified to account for modern and contemporary schools. Thus, he may be perceived for example as a Thomistic phenomenologist, or an open Thomist when we look at him through the prism of established philosophy schools. But there is also another possible way of looking at his work.

We may sketch it out by starting from a methodological question: was Wojtyła interested in and fascinated by great philosophers and their achievements more than in philosophical problems themselves? At first glance, there is no easy answer. We can see him involved as much in the thought of Max Scheler as in the analysis of human love, to give just one example. However, a more careful reading of Wojtyła's works reveals that although he began with great philosophical figures (Thomas Aquinas, Immanuel Kant, Max Scheler), he gradually became more interested in problems and their solutions. 
It is said that when Karol Wojtyła was a professor at the Catholic University of Lublin, on one occasion he exchanged his views and opinions with another famous scholar of the Lublin School, Stanisław Kamiński. Such an exchange was nothing new. The circle of philosophers gathered around the famous Mieczysław Albert Krąpiec often engaged in philosophical discussions and debates. Kamiński was renowned as a brilliant expert in the methodology of philosophy. He confronted Wojtyła after the publication of his Acting Person, reproaching him for including so few references and quotations in this book. Wojtyła's reply was interesting; he said: "All right, you are a scholar, but I am a thinker." This scene suggests quite clearly that the Polish philosopher, especially in the later period - the late 6os and early 7os - was more interested in shedding some light on the realty of the human person than in strictly following academic rules in his publications.

Such an assessment of Wojtyła's philosophizing is confirmed by Jarosław Merecki, a philosopher closely related to Tadeusz Styczeń. The latter, as is well known, was a close collaborator of Wojtyła and then of John Paul II. Merecki explicitly says that "as a philosopher, Wojtyła knew how to gather semi veritatis scattered in diverse philosophical schools. It was so because Wojtyła was not loyal to this or that philosopher in the first place, but to the reality itself as given in the experience." ${ }^{\prime}$ After his encounter with phenomenology, the Polish thinker appreciated experience very much and it seems that it was for him a kind of locus philosophicus. When we read his main work, The Acting Person, we quickly realize that one of the words he uses most frequently is just "experience."

Today we are witnessing a very strange situation in contemporary philosophy: the discipline seems to be concerned with itself more and more. Many philosophers move from real problems, those concerning human life, society and culture, and spend their time and energy on philosophy itself. In this move there is a strong tendency to escape

\footnotetext{
6 J. Merecki, Corpo e transcendenza. L'antropologia filosofica nella teologia del corpo di Giovanni Paolo II, Siena 2015, p. 30.
} 
from philosophy to metaphilosophy. As a result, we have at least two consequences: firstly, that we abandon what has been the everlasting vocation of philosophers, namely solving problems or preparing the grounds for this; secondly, philosophy concerned with itself enhances the spirit of skepticism about thinking itself. As a result, everything can be relativized and we are on a straight path to nihilism. Wojtyła's attitude reminds us about the fundamental tasks of philosophy and its positive and constructive role.

\section{Back to the Human Person}

Karol Wojtyła engaged in various activities in his lifetime. Among those associated with his academic life, we can see a special concentration on the human being. In theater, poetry, literature, theology he was concerned with the drama experienced by the human person in relation to God, to others and to him - or herself. His involvement in the philosophical theory of personhood was an extension of that interest. It matured slowly and gradually and took its final form in The Acting Person. This is Wojtyła's masterpiece, which reveals his original thought on the person, while at the same time opening up new avenues for investigating the person. This book has in its background not only the philosophers he drew upon (whom we have mentioned above), but also the entire modern and contemporary anthropological tradition with its positive and critical moments.

When Wojtyła was working on this important treatise, he wrote a letter to the great French theologian Henri de Lubac in which he acknowledged a very important thing. Wojtyła confessed: "I devote my very rare free moments to a work that is close to my heart and is devoted to the metaphysical sense and mystery of the person. The evil of our times consists in the first place in a kind of degradation, indeed in a pulverization, of the fundamental uniqueness of each human person." ${ }^{\text {" We do }}$ not know exactly what was on Wojtyła's mind when he pointed to those

7 Cited after: J. F. Crosby, The Personalism of John Paul II, Steubenville 2019, p. 9. 
menaces threatening the reality of the human person. However, knowing the academic and cultural context of the world of the late 6os, including its state of philosophy, we can point to such well-known schools like Marxism, structuralism or existentialism. All of them, in their own way, undermined the reality of the human person by claiming that either the person is a product of society and should be subjected to it, or by arguing that there is only a sui generis individual closed in himself and creating himself, or challenging the very existence of a person (there are only various non-human structures which secondarily give rise to other entities, including the human person). All of them lead to what Wojtyła calls "degradation" and "pulverization" of the fundamental uniqueness of a person. The Acting Person then was to stem those assaults on the human being and direct attention to his uniqueness, richness and unrepeatability.

Today's social and philosophical context is far more complex, but at the same time we still face threats of degradation and pulverization of the human person. They come from various sources and we can identify some of them. Firstly, there is a tendency to question the existence of the human subject and to attempt to replace him with a stream of consciousness, which is in turn understood as the entire product of the human brain. Secondly, there is also a well-established tendency to question the existence of the person and concentrate on selected personal characteristics. Such characteristics can then be ascribed to various entities, for example, to some humans, animals and even artificial machines. In the latter case, some argue that we can create artificial and autonomous subjects. Thirdly, in transhumanism the human person is considered as a structure which should be overcome and replaced by a post-human person, meaning a better, fitter and more advanced (as far as his characteristics are concerned) person. Fourthly, within a radical environmental philosophy there is a conviction that the human person is one of the entities of the material world and his status should be made equal to that of other living creatures. In order to avoid a speciesism and promote an environmental egalitarianism, we should withdraw from insisting on a special status and moral importance of the human being. 
The philosophy developed and handed down to us by Karol Wojtyła should face up to all those tendencies. What we have inherited from this great Polish personalist is a basic conviction that the human person cannot be reduced to the natural world, that the person possesses his/her interiority, which reveals an enormous richness of personality and spirit. Wojtyła gives us weapons to fight with anthropological reductionism and scientism. It means that in a critical exchange with the aforementioned tendencies we can use many Wojtylian ideas, even if he does not offer us ready-made strategies of how to conduct such a discussion.

\section{Philosophy Neglected?}

If there are so many important areas where Wojtyła's philosophizing can be applied, why are his ideas and projects so little known? His main works have been translated into many contemporary languages, why have they not made much of an impact? Of course, his ideas have been discussed in theological circles because of studies on papal documents. Theologians are well familiar with them. However, few scholars are familiar with the original philosophy developed by Wojtyła. Why is that? - we may ask.

At least two answers may be provided. Firstly, some contemporary philosophers - even in Catholic academic centers - do not consider him a philosopher. Maybe they are suspicious of him because of his later involvement in ministry as the Pope and consider his philosophical books as preliminary works for his magisterial writings (philosophia ancilla theologiae)? Maybe, they are afraid that crediting him with the status of a philosopher will strengthen the status of the Catholic theology as a truly universal message addressed to and able to be received by people of all faiths and of no faith as well? Additionally, in the model of philosophy open to theology (which is typical for Wojtyła) many philosophers perceive a danger and betrayal of philosophy itself. There are still some tensions between theology and philosophy and especially many philosophers have a skeptical attitude toward theology. 
Secondly, an answer comes strictly from the Catholic environment. Rocco Buttiglione speaks directly about fears among Catholic intellectuals in discussing Wojtyła's ideas because of alleged dangers to his papal writings. ${ }^{8}$ Karol Wojtyła as John Paul II participated in the creation of many encyclicals, exhortations and papal letters. They are saturated with ideas coined and developed by Karol Wojtyła as a philosopher earlier on. Thus, some Catholic commentators may reason in the following way: "Discussing the latter in a strictly philosophical and critical manner, we may weaken the former. Hence, in order to guard the teaching of the Pope, we shall refrain from problematizing its philosophical underpinnings."

At any rate, we should respond to all these false strategies and concerns by looking closely at what the philosopher accomplished. Karol Wojtyła was an original thinker and he left us a great deal of good personalistic philosophy. In some places further refinement can and should be done to polish it. What is interesting is that the Polish thinker himself acknowledged that need a number of times. However, what he worked out philosophically was interesting, inspiring and relevant. It is still valid because a body of his publications constitutes a rich collection of resources which may be helpful in dealing with contemporary dilemmas. His philosophy does not need any apologetic assistance or support: it can defend itself on its own. The better we understand his rational thinking, the better view we get of his theology. For Wojtyła, good theology is always preceded by good philosophy, and vice versa - theology is not a dangerous rival for philosophy. We can paraphrase his famous saying from Fides et ratio and declare explicitly that philosophical and theological knowledge are like two wings helping us to attain the whole truth of the human person.

8 Buttiglione put it this way, "Wojtyła è un filosofo importante che è rimasto relativamente poco noto e studiato perché dopo la sua elezione al Pontificato era in effetti alquanto imbarazzante confrontarsi con il pensiero di un filosofo che era contemporaneamente Papa" (R. Buttiglione, Sulla verità soggettiva. Esiste unialternativa al dogmatismo e allo scetticismo?, Catanzaro 2015, p. 286). 


\section{Toward Conclusions}

Karol Wojtyła's philosophy cannot be relegated to a repository of the history of philosophy. We cannot responsibly claim that what he wrote is only understandable in the context of the second half of the twentieth century and has no bearing on the problems we experience and deal with right now. The opposite is actually true. We have good reasons to perceive Wojtylan philosophical heritage as a rich reservoir of resources for thinking over the problems which beset us today. Wojtyła developed many interesting and inspiring ideas and projects which are deeply rooted in the achievements of great figures of the past, and his voice is in a sense empowered by their ingenuity and authority. However, his project in its entirety is his own creation and, as far as its content is concerned, is strictly focused on the human person.

What should be done with this original heritage further on? Some suggestions have been already been made. Organizing and complementing them, we can point to three stages. First, we should pay careful attention to what Wojtyła really wanted to say as a philosopher. This is not an easy step, because in many places his ideas are quite complex and speculative. Second, we should undertake an attempt to complete and touch up his projects. In a sense, he himself commissioned us to do that by claiming that some parts of his undertakings require further refinement. Third, we should contemplate how to use Wojtylian ideas to deal with contemporary problems, especially in the realm of ethics and philosophy of the human person. This stage seems to be the most demanding because in many situations a straightforward application of his ideas is not an option. We should get round to creatively employing this important heritage, and while this may be done within Christian philosophy, its potential extends far beyond it. ${ }^{9}$ This approach may take many forms and in fact represents an open field of investigation. How to do that is a topic for another article.

9 See e. g. G. Hołub, The Human Subject and Its Interiority. Karol Wojtyła and the Crisis in the Philosophical Anthropology, "Quién” 2016 no. 4, p. 47-66. 


\section{Bibliography}

Buttiglione R., Sulla verità soggettiva. Esiste unialternativa al dogmatismo e allo scetticis$m o$ ?, Catanzaro 2015.

Crosby J. F., The Personalism of John Paul II, Steubenville 2019.

Hołub G., Biesaga T., Merecki J., Kostur M., Karol Wojtyła, Kraków 2019.

Hołub G., The Human Subject and Its Interiority. Karol Wojtyła and the Crisis in the Philosophical Anthropology, "Quién” 2016 no. 4, p. 47-66.

John Paul II, Crossing the Threshold of Hope, New York 2005.

Merecki J., Corpo e transcendenza. Lantropologia filosofica nella teologia del corpo di Giovanni Paolo II, Siena 2015.

Wojtyła K., Love and Responsibility, transl. H. T. Willetts, San Francisco 1981.

Wojtyła K., Osoba i czyn, Kraków 1969.

Wojtyła K., Person: Subject and Community, in: K. Wojtyła, Person and Community. Selected Essays, transl. T. Sandok, New York 1993, p. 219-261.

\section{Abstract}

\section{The Validity of Karol Wojtyła's Philosophy Today}

The article deals with the problem of the importance of Karol Wojtyła's philosophy. He is shown as a thinker interested in the achievements of many philosophers throughout history, like Aristotle, St. Augustin, Thomas Aquinas, Immanuel Kant or Max Scheler. However, he is also presented as someone who undertook his own way of philosophizing focused on the human person. Therefore the article underlines Wojtyła's dialogue with other philosophers at the time when he was developing his own philosophical standpoint. Moreover, his philosophy is shown as a discipline associated with real problems rather than with meta-philosophical ones. The article also discusses Wojtyła's philosophy of the human person and how it can deal with anti-personalist tendencies in contemporary philosophy. Finally, the author considers some difficulties associated with the philosophy of Wojtyła and how it should be developed in the future.

\section{Keywords}

Karol Wojtyła, project of philosophy, human person 